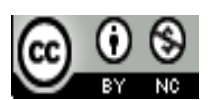

Jurnal Pendidikan Matematika Indonesia is licensed under

A Creative Commons Attribution-Non Commercial 4.0 International License

\title{
Efektivitas Model Pembelajaran Creative Problem Solving (CPS) Dalam Meningkatkan Kemampuan Berfikir Kritis Matematis Siswa Pada Materi Persamaan Garis Lurus
}

\author{
Rika Wahyuni $^{1)}$, Mariyam ${ }^{2)}$, Dewi Sartika ${ }^{3)}$ \\ 1) STKIP Singkawang, Singkawang, Indonesia \\ E-mail: Rikawahyuni142@gmail.com \\ ${ }^{2)}$ STKIP Singkawang, Singkawang, Indonesia \\ E-mail: mariyam.180488@gmail.com \\ 3) STKIP Singkawang, Singkawang, Indonesia \\ E-mail: sartikad270@yahoo.co.id
}

\begin{abstract}
Abstrak. Penelitian ini bertujuan untuk: 1) Mengetahui ketercapaian ketuntasan siswa pada materi persamaan garis lurus setelah diterapkannya model pembelajaran CPS; 2) Mengetahui perbedaan peningkatan kemampuan berfikir kritis matematis siswa pada materi persamaan garis lurus antara siswa yang mendapat pembelajaran dengan model pembelajaran CPS dan yang mendapat model pembelajaran langsung; 3) Mengetahui aktivitas belajar siswa selama diterapkannya model pembelajaran CPS. Penelitian ini menggunakan desain Quasi Eksperimental dengan bentuk The Nonequivalent Control Group Design. Sampel dalam penelitian ini terdiri dari 2 kelas yang dipilih dari 4 kelas. Pengambilan sampel menggunakan teknik purposive sampling dan terpilihlan kelas VIII B sebagai kelas eksperimen dan kelas VIII C sebagai kelas kontrol. Pertimbangan dipilihnya kedua kelas tersebut karena masih banyak siswa yang mengalami kesulitan dalam belajar dan rata-rata ketuntasan siswa belum mencapai KKM. Hasil analisis data menunjukkan bahwa: 1) Siswa mencapai ketuntasan secara individu maupun klasikal pada kelas yang menggunakan model pembelajaran $C P S$ 2) Terdapat perbedaan peningkatan kemampuan berfikir kritis matematis antara siswa yang diberikan model pembelajaran CPS dengan siswa yang diberikan model pembelajaran langsung; 3) Aktivitas siswa tergolong aktif selama diterapkan model pembelajaran $C P S$.
\end{abstract}

Kata Kunci : Model Pembelajaran Creative Problem Solving, Ketuntasan Belajar, Kemampuan Berfikir Kritis, Aktivitas Belajar.

\section{PENDAHULUAN}

Matematika merupakan ilmu dasar dalam perkembangan ilmu pengetahuan dan teknologi yang semakin berkembang pesat. Oleh karena itu, matematika merupakan salah satu mata pelajaran dalam pendidikan formal yang wajib dipelajari di setiap jenjang pendidikan di Indonesia. Hal ini dikemukakan oleh Depdiknas (2007:345) bahwa matematika perlu diberikan kepada semua siswa mulai dari sekolah dasar untuk membekali siswa agar memiliki kemampuan berfikir logis, analitis, sistematis, kritis dan kreatif serta kemampuan bekerjasama. Selanjutnya Permendikbud Nomor 20 Tahun 2016 mensahkan Standar Kompetensi Lulusan (SKL) mata pelajaran Matematika SMP/MTs/SMPLB/PAKET B yang salah satunya ialah siswa harus memiliki keterampilan berfikir kritis, produktif, kreatif, mandiri, dan kolaboratif dan komunikatif. Dari keenam dimensi keterampilan tersebut kemampuan berfikir kritis merupakan kemampuan yang harus dimiliki siswa siswa karena merupakan bagian dari SKL mata pelajaran matematika.

Hal yang sama juga dikemukakan National council of teacher of mathematics (NCTM), bahwa kurikulum dan evaluasi disusun sebagai suatu standar dalam usaha memberi kesempatan kepada siswa dalam berbagai tingkat satuan pendidikan untuk mendapatkan informasi secara kritis hal ini menunjukkan bahwa kemampuan berfikir tingkat tinggi termasuk berfikir kritis menjadi salah satu tujuan dalam penyusunan kurikulum (NCTM, 2000).

Berfikir kritis merupakan pemfokusan suatu pikiran untuk memutuskan apa yang diyakini untuk dilakukan (Baron, 1987: 224). Sejalan dengan itu, menurut Ennis (1991: 54) dengan berpikir kritis dapat meningkatkan kemampuan berpikir secara rasional dan reflektif yang bertujuan untuk mengambil keputusan tentang apa yang diyakini atau dilakukan. Jadi 
berpikir kritis adalah proses berpikir yang sistematis yang memungkinkan siswa untuk .

Merumuskan dan memutuskan keyakinannya sendiri serta mengevaluasi setiap keputusannya dengan tepat. Maka berfikir kritis juga dapat diartikan sebagai kemampuan menganalisis suatu permasalahan. Sesuai dengan hal tersebut dalam pembelajaran matematika, kemampuan berfikir siswa sangat penting. Dengan berfikir, siswa akan berusaha menemukan masalah dan berusaha menyelesaikannya. Dari pemaparan di atas maka dapat disimpulkan bahwa kemampuan berfikir kritis merupakan faktor yang berpengaruh dalam pembelajaran matematika.

Namun beberapa hasil penelitian menunjukkan bahwa kemampuan berfikir kritis siswa masih rendah, Berdasarkan hasil penelitian yang dilakukan oleh Hidayanti (2016) menunjukan bahwa kemampuan berpikir kritis siswa SMP kelas IX masih tergolong rendah pada indikator mengidentifikasi, evaluasi, dan inferensi. Hal serupa juga terjadi pada siswa di SMP Negeri 12 Singkawang. Berdasarkan hasil prariset yang dilakukan di SMP Negeri 12 Singkawang peneliti mendapatkan bahwa kemampuan berfikir kritis matematis siswa masih relative rendah peneliti memberikan soal yang mengandung 3 indikator kemampuan berfikir kritis kepada siswa. Berdasarkan hasil prariset yang dilakukan di SMP Negeri 12 Singkawang pada soal nomor 1 butir a sebagian besar siswa sudah dapat menjawab dengan benar yaitu terdapat 27 siswa dari 30 siswa ( $81.81 \%$ ), pada soal nomor 1 butir b dari keseluruhan yaitu 30 siswa, hanya terdapat 13 siswa yang dapat menjawab dengan benar atau sebesar $39.39 \%$. Pada soal nomor 1 butir c hanya beberapa siswa yang bisa menjawab dengan benar, yaitu terdapat 10 siswa dari 30 siswa yang dapat menjawab dengan benar atau sebesar $30.30 \%$. Dari hasil prariset tersebut dapat disimpulkan bahwa kemampuan berfikir kritis matematis masih tergolong rendah. Rendahnya kemampuan siswa dalam berfikir kritis, disebabkan kurangnya pemahaman siswa dalam mengidentifikasikan asumsi, menemukan cara penyelesaian, kemudian menggunakannya dalam menyelesaikan masalah.

Selain melakukan prariset, peneliti juga melakukan observasi di dalam kelas untuk melihat aktivitas siswa selama proses pembelajaran matematika.Hasil observasi yang diperoleh peneliti di SMPN 12 Singkawang adalah aktivitas belajar siswa masih tergolong rendah. Rendahnya aktivitas siswa tersebut terlihat dari kurangnya pertanyaan siswa terhadap materi yang dianggap belum paham dan tanggapan siswa apabila diberikan pertanyaan yang terkait dengan materi pelajaran cenderung pasif, selain itu dalam mengerjakan latihan - latihan soal siswa cenderung mengikuti langkah langkah yang digunakan oleh guru, siswa juga tidak semangat dalam pembelajaran dan cepat bosan dalam belajar matematika hal ini akan berdampak pada hasil yang kurang memuaskan dan nilai yang didapat tidak sesuai dengan yang diharapkan.

Satu di antara materi matematika yang berperan penting dalam kehidupan sehari-hari adalah persamaan garis lurus. Persamaan garis lurus merupakan bagian dari materi matematika SMP kelas VIII semester gasal yang menuntut pemikiran siswa untuk menemukan konsep rumus secara kretif dan teliti dalam menyelesaikan soal-soal yang berkaitan dengan persamaan garis lurus, peneliti mendapatkan informasi dari salah satu guru mata pelajaran matematika kelas VIII SMP Negeri 12 Singkawang bahwa masih banyak siswa yang tidak memahami dan masih merasa kesulitan dalam menyelesaikan soal persamaan garis lurus. Persamaan garis lurus merupakan salah satu materi yang dianggap sulit untuk dipecahkan. Siswa kesulitan dalam menentukan titik-titik dalam bidang kartesius yang merupakan langkah pertama dalam pembuatan grafik persamaan garis lurus siswa juga kebingungan dalam menyelesaikannya terutama dalam soal cerita siswa kesulitan untuk menerjemahkan soal ke dalam bentuk grafik dan membayangkan dari bentuk gambar ke bentuk yang sebenarnya dan sebaliknya, sehingga banyak siswa yang tidak tuntas pada materi persamaan garis lurus..

Rendahnya kemampuan dan kurangnya aktivitas siswa diduga disebabkan oleh proses pembelajaran yang masih berpusat pada guru. Proses pembelajaran matematika saat ini masih cenderung menerapkan model pembelajaran konvensional, maka dapat ditegaskan bahwa usaha perbaikan proses pembelajaran melalui upaya pemilihan model pembelajaran yang tepat dan inovatif dalam pembelajaran matematika di sekolah merupakan suatu kebutuhan yang sangat penting untuk dilakukan. Salah satu model pembelajaran yang diduga dapat digunakan untuk memperbaiki kualitas proses dan hasil belajar adalah model pembelajaran $C P S$.

Model pembelajaran CPS memiliki ciri-ciri seperti pembelajaran dimulai dengan pemberian masalah, masalah memiliki konteks dengan dunia nyata, siswa secara berkelompok aktif merumuskan masalah dan mengidentifikasi kesenjangan pengetahuan mereka, mempelajari dan mencari sendiri materi yang terkait dengan masalah dan melaporkan solusi dari masalah. Sementara pendidik lebih banyak memfasilitasi (Istarani, 2015:136)

Model pembelajaran CPS adalah suatu model pembelajaran yang memusatkan pada pengajaran dan ketrampilan pemecahan masalah, yang diikuti dengan penguatan ketrampilan (Pepkin, 2004:1). Dengan memecahkan sebuah masalah dapat membantu siswa berfikir kritis (Daniel, 2016:8) model pembelajaran ini diharapkan dapat meningkatkan ketuntasan belajar serta aktvitas siswa 
dalam mempelajari matematika, sehingga siswa dapat memperoleh manfaat yang maksimal baik dari proses maupun hasil belajarnya.

Hasil penelitian Mahmuda (2015) juga menyimpulkan bahwa model pembelajaran CPS memberikan pengaruh lebih efektif dibandingkan dengan model pembelajaran konvensional. Hal ini dapat dilihat dari perbedaan antara nilai rata-rata posttest kelas eksperimen yang cenderung lebih tinggi dibandingkan dengan rata-rata posttest kelas kontrol.

Berdasarkan latar belakang di atas penulis tertarik untuk mencoba menerapkan model pembelajaran CPS khususnya pada materi persamaan garis lurus. Oleh karena itu pada penelitian ini peneliti tertarik mengambil judul "Efektifitas model pembelajaran Creative Problem Solving (CPS) dalam meningkatkan kemampuan berfikir kritis matematis siswa pada materi persamaan garis lurus".

\section{METODE}

Jenis penelitian ini adalah jenis penelitian kuantitatif dengan metode eksperimen. Desain penelitian yang digunakan dalam penelitian ini adalah desain penelitian Quasi Eksperimental dengan rancangan Nonequivalent Control Grup Design. Terdapat dua kelas dalam penelitian ini yaitu kelas pertama disebut sebagai kelas eksperimen dan kelas kedua disebut sebagai kelas kontrol. Adapun sekolah yang menjadi tempat penelitian adalah di SMP Negeri 12 Singkawang kelas VIII yang beralamat di Jalan Ratu Sepudak Kelurahan Sungai Rasau Kecamatan Singkawang Utara. Populasi dalam penelitian ini adalah seluruh kelas VIII SMP Negeri 12 Singkawang yang terdiri dari empat kelas yaitu VIII A, VIII B, VIII C, VIII D yang berjumlah 84 siswa. Teknik pengambilan sampel pada penelitian ini dengan menggunakan teknik purposive sampling. Adapun yang menjadi kelas eksperimen adalah kelas VIII B dan kelas kontrol adalah kelas VIII C.

Teknik analisis data yang digunakan dalam penelitian ini adalah analisis kuantitatif dengan statistika. Dalam penelitian ini akan diperoleh data kuantitatif sehingga untuk menganalisis data didapatkan dari pemberian tes hasil belajar dan pegamatan menggunakan lembar aktivitas akan dilakukan teknik statistik.

\section{HASIL DAN PEMBAHASAN}

\section{Ketuntasan Hasil Belajar Siswa}

Ketuntasan belajar siswa dilihat dari nilai postest berdasarkan uji normalitas data postest di peroleh hasil perhitungan yang akan disajikan pada Tabel I

TABEL I

REKAPITULASI UJI NORMALITAS

DATA POSTTEST KELAS EKSPERIMENT

\begin{tabular}{ccc}
\hline$x^{2}$ hitung & $x^{2}$ tabel & Keterangan \\
5,6718 & 9,488 & $\begin{array}{c}\text { Berdistribusi } \\
\text { normal }\end{array}$ \\
\hline
\end{tabular}

Berdasarkan Tabel I diketahui bahwa nilai $x^{2}$ hitung $<x^{2}$ tabel $x^{2}$ hitung $<x^{2}$ tabel yaitu $5,6718<9,488$ yang menurut kriteria berarti data berdistribusi normal. Data berdistribusi normal maka akan dilakukan pengujian untuk menentukan ketuntasan belajar individual dan ketuntasan belajar klasikal.

\section{a. Ketuntasan individual}

Ketuntasan individual merupakan rata-rata siswa yang mencapai nilai KKM yang diterapkan disekolah yaitu 70 . Ketuntasan individual ini akan dihitungan menggunakan rumus $t$ - test one sampel dan dapat dilihat pada Tabel II

TABEL II

REKAPITULASI KETUNTASAN BELAJAR INDIVIDUAL SISWA

\begin{tabular}{ccc}
\hline$t_{\text {hitung }}$ & $\boldsymbol{t}_{\text {tabel }}$ & Keterangan \\
\hline 2,85 & 1,725 & Mencapai KKM 70 \\
\hline
\end{tabular}

Dari Tabel II diperoleh nilai $t_{\text {hitung }}$ ketuntasan individual siswa kelas eksperimen adalah 2,85. Dengan $\mathrm{dk}=(21-1)$ maka harga $t_{\text {tabel }}$ dan taraf signifikannya $5 \%=1,725$. Karena $t_{\text {hitung }}>>t_{\text {tabel }}$ atau $2,85>1,725$ dengan krteria pengujian hipotesis maka Ho ditolak dan Ha diterima, sehingga dapat disimpulkan bahwa rata-rata ketuntasan hasil siswa dikelas eksperimen atau kelas yang menggunakan model pembelajaran Creative Problem Solving mencapai KKM yaitu 70

b. Ketuntasan belajar klasikal

Ketuntasan belajar klasikal merupakan proporsi siswa yang mendapat nilai $\mathrm{KKM} \leq 70$. Proporsi yang ditetapkan dalam penelitian ini adalah $75 \%$. Untuk mengetahui ketuntasan klasikal ini akan digunakan rumus proporsi. Dan dapat dilihat pada Tabel III

TABEL III

REKAPITULASI KETUNTASAN BELAJAR KLASIKAL SISWA

\begin{tabular}{cccc}
\hline Kelas & $Z_{\text {hitung }}$ & $Z_{\text {tabel }}$ & Keterangan \\
\hline Eksperimen & 1,11 & 0,45 & $\begin{array}{c}\text { Nilai KKM } \geq 70 \\
\text { mencapai } 75 \%\end{array}$ \\
\hline
\end{tabular}

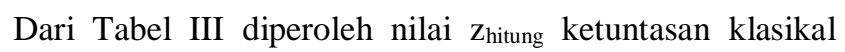
siswa kelas eksperimen adalah 1,11. Dengan $\mathrm{z}$ tabel dengan taraf kesignifikan $5 \%$ dengan demikian $Z_{\text {hitung }}>>Z_{\text {tabel }}$ atau $1,11>0,45$ dengan krteria pengujian hipotesis maka Ho ditolak dan Ha diterima, sehingga dapat disimpulkan bahwa proporsi ketuntasan siswa secara klasikal mendapat nilai $\mathrm{KKM} \geq 70$ Mencapai $75 \%$.

Berdasarkan hasil ketuntasan belajar siswa diperoleh bahwa kemampuan berfikir kritis matematis siswa pada kelas eksperimen mencapai ketuntasan belajar secara individual dan mencapai ketuntasan belajar secara klasikal. Hal ini karena dengan di terapkannya pembelajaran dengan menggunakan model pembelajaran Creative Problem Solving. 


\section{일.}

\section{Kemampuan Berfikir Kritis Matematis Siswa}

Hasil pengumpulan data selama penelitian diperoleh data hasil pretest dan posttest (berupa skor) dari kelas yang diajarkan dengan model pembelajaran Creative Problem Solving untuk kelas eksperimen dan pembelajaran langsung untuk kelas kontrol terhadap kemampuan berfikir kritis matematis siswa pada materi persamaan garis lurus. Adapun soal pretest dan posttest yang diberikan berbentuk tes kemampuan berfikir kritis matematis sebanyak sembilan soal dengan tiga indikator.

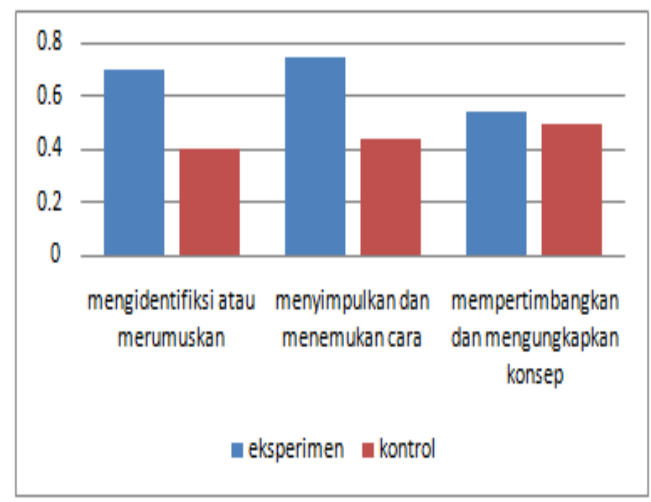

Gambar 1. Diagram Batang Nilai Rata-rata N-Gain Kelas Eksperimen dan Kelas Kontrol Berdasarkan Per-Indikator Kemampuan Berfikir Kritis

Dari Gambar 1 diketahui bahwa setiap indikator kemampuan berfikir kritis matematis siswa baik pada kelas eksperimen dan kelas kontrol mengalami peningkatan. Namun nilai $\mathrm{N}$-Gain pada kelas eksperimen untuk setiap indikator kemampuan berfikir kritis matematis siswa lebih tinggi dibanding nilai N-Gain pada kelas kontrol. Hal ini menunjukan bahwa peningkatan yang terjadi dikelas eksperimen lebih tinggi dibandingkan dengan peningkatan yang terjadi pada kelas kontrol. Selanjutnya secara keseluruhan indikator kemampuan berfikir kritis siswa nilai $\mathrm{N}$-Gain pada kelas eksperimen juga lebih tinggi dibandingkan nilai N-Gain pada kelas kontrol. Perbandingan N-Gain keseluruhan indikator kemampuan berfikir kritis siswa dapat dilihat pada gambar diagram batang 2 sebagai berikut.

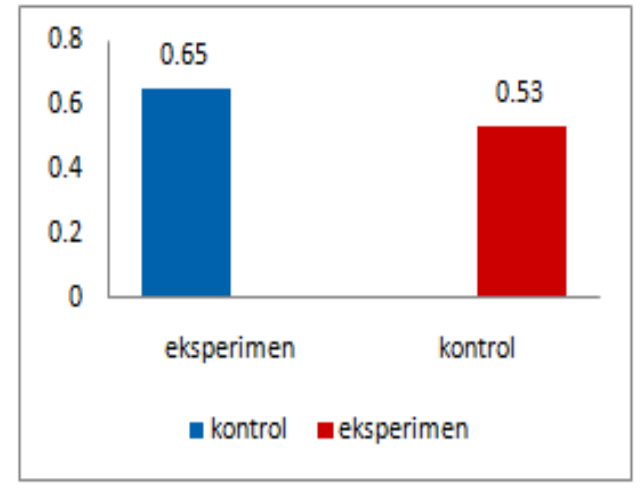

Gambar 2. Diagram Batang Nilai Rata-rata N-Gain Keseluruhan Indikator Kemampuan Berfikir Kritis Matematis siswa Kelas Eksperimen dan Kelas Kontrol
Dari Gambar 1 dan 2 menunjukan bahwa secara deskriptif rata-rata $\mathrm{N}$-gain antara kelas kontrol dan kelas eksperimen berbeda, namun secara inferensial nilai tersebut belum tentu memiliki perbedaan yang signifikan. Untuk melihat perbedaan peningkatan antara kelas yang menggunakan model pembelajaran Creative Problem Solving dengan kelas yang menggunakan model pembelajaran langsung (kelas kontrol) maka menggunakan uji-t dua sampel independen. Sebelum uji-t dua sampel independen digunakan maka terlebih dahulu menggunakan uji normalitas data dan selanjutnya uji homogenitas.

Berdasarkan hasil perhitungan, didapat untuk $\mathrm{N}$-Gain kelas eksperimen dan kontrol akan disajikan sebagai berikut:

TABEL IV

REKAPITULASI PERHITUNGAN N-GAIN KELAS EKSPERIMEN DAN KONTROL

\begin{tabular}{lccc}
\hline & $\begin{array}{c}\text { N-Gain kelas } \\
\text { Kontrol }\end{array}$ & $\begin{array}{c}\text { N-Gain kelas } \\
\text { Eksperimen }\end{array}$ \\
\hline$x^{2}{ }_{\text {hitung }}$ & $\mathbf{6 , 5 3 5 5}$ & & $\mathbf{5 , 6 7 1 8}$ \\
$x_{\text {tabel }}$ & $\mathbf{9 , 4 8 8}$ & $\mathbf{0 , 6 2}$ & $\mathbf{9 , 4 8 8}$ \\
$F_{\text {hitung }}$ & & $\mathbf{6 , 3 9}$ & \\
$F_{\text {tabel }}$ & & & \\
\hline
\end{tabular}

$t_{\text {hitung }}^{\text {Dari }}>t_{\text {tabel }}^{\text {hasil }} t_{\text {hitung }}>t_{\text {tabel }}$ yaitu 5,978 $>1,684$ yang menurut kriteria berarti Ho ditolak dan Ha diterima dengan taraf signifikan 5\% atau 0,05 sehingga dapat disimpulkan bahwa terdapat perbedaan peningkatan yang signifikan antara kelas eksperimen dan kelas kontrol yaitu kemampuan berfikir kritis matematis siswa kelas kelas eksperimen lebih tinggi dibanding kemampuan berfikir kritis matematis siswa kelas kontrol.

Perbedaan peningkatan kemampuan berfikir kritis matematis siswa tersebut disebabkan adanya perbedaan yang ditimbulkan oleh masing-masing perlakuan dalam pembelajaran. Peningkatan kemampuan berfikir kritis matematis siswa yang lebih tinggi pada kelas eksperimen yang menggunakan model pembelajaran Creative Problem Solving.

\section{Aktivitas Belajar Siswa}

Lembar observasi digunakan untuk mengetahui aktivitas siswa selama mengikuti pembelajaran dengan menggunakan model pembelajaran Creative Problem Solving. Pengamatan yang dilakukan selama dua kali pertemuan yang dilakukan oleh 3 orang pengamat, persentase hasil pengamatan aktivitas siswa selama dua pertemuan dapat dilihat pada gambar diagram batang 3 sebagai berikut. 


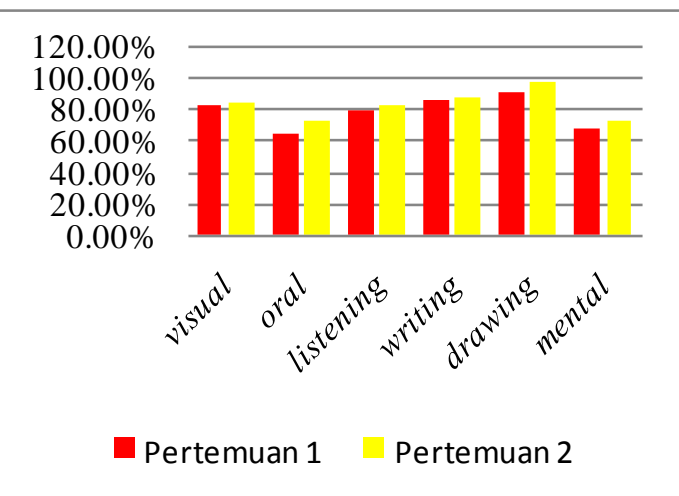

\section{Gambar 3. Diagram Batang Nilai Rata-rata $N$-Gain Keseluruhan Indikator Kemampuan Berfikir Kritis Matematis siswa Kelas Eksperimen dan Kelas Kontrol}

Dari Gambar 3 dapat dilihat persentase rata-rata aktivitas pada pertemuan pertama dan kedua pada kategori pengamatan visual activities dengan tiga aktivitas yang diamati sekitar 17 orang siswa yang dalam persentase sebesar $83,07 \%$ pada pertemuan pertama dan $84,66 \%$ sebanyak 18 orang pada pertemuan kedua. Pada kategori pengamatan oral activities dengan satu akivitas yang diamati sekitar 14 orang siswa yang dalam persentase sebesar persentase sebesar $65,08 \%$ untuk pertemuan pertama dan $73,02 \%$ sebanyak 16 orang untuk pertemuan kedua. Pada kategori listening activities yang terdiri dari tiga aktivitas yang diamati sekitar 21 orang siswa yang dalam persentase sebesar persentase sebesar $79,89 \%$ pada pertemuan pertama dan $84,13 \%$ pada pertemuan kedua. Pada kategori pengamatan writting activities yang terdiri dari dua aktivitas yang diamati diperoleh persentase sebesar $87,30 \%$ pada pertemuan pertama dan $88,10 \%$ pada pertemuan kedua, pada kategori drawing activities yang terdiri dari satu aktivitas yang diamati sekitar 21 orang siswa yang dalam persentase sebesar persentase sebesar $92,06 \%$ pada pertemuan pertama dan $98,41 \%$ pada pertemuan kedua. Sedangkan pada kategori mental activities terdapat dua aktivitas yang diamati sekitar 21 orang siswa yang dalam persentase sebesar persentase sebesar $69,05 \%$ pada pertemuan pertama dan $73,02 \%$ pada pertemuan kedua.

Dari data persentase aktivitas siswa diperoleh rata-rata dari enam kategori pengamatan, dua kali pertemuan dan tiga orang pengamat yaitu sebesar $81,61 \%$. Hal ini menunjukkan bahwa aktivitas siswa selama pembelajaran berlangsung berada pada kategori sangat aktif. Dengan demikian dapat disimpulkan bahwa aktivitas siswa tergolong aktif pada pembelajaran materi persamaan garis lurus dengan menggunakan model pembelajaran creative problem solving. mampu membuat siswa aktif selama proses pembelajaran berlangsung.
IV. KESIMPULAN

Berdasarkan hasil pengelolaan data hasil penelitian dan pembahasan secara umum dapat disimpulkan bahwa model pembelajaran CPS dikatakan efektif untuk meningkatkan kemampuan berfikir kritis matematis siswa pada materi persamaan garis lurus kelas VIII SMP Negeri 12 Singkawang. Hal ini karena memenuhi ketiga kriteria efektifitas. Sesuai dengan sub-sub rumusan masalah penelitian, secara khusus dapat disimpulkan hal-hal sebagai berikut.

1. Kemampuan berfikir kritis matematis siswa pada materi persamaan garis lurus yang diajarkan dengan menggunakan model pembelajaran Creative Problem Solving telah mencapai ketuntasan secara individu maupun klasikal.

2. Terdapat perbedaan peningkatan kemampuan berfikir kritis matematis antara siswa yang mendapatkan model pembelajaran Creative Problem Solving dengan siswa yang mendapatkan model pembelajaran langsung pada materi persamaan garis lurus kelas VIII SMP Negeri 12 Singkawang.

3. Aktivitas belajar siswa tergolong aktif selama pembelajaran menggunakan model pembelajaran Creative Problem Solving.

\section{UCAPAN TERIMAKASIH}

Penulis mengucapkan terima kasih kepada seluruh dosen Pendidikan Matematika STKIP Singakwang, kepada Ketua STKIP Singkawang Drs. Andi Mrsidi, M.Si yang telah memberikan arahan dan bimbingan dalam penulisan artikel hasil penelitian ini.

\section{DAFTAR PUSTAKA}

Baron, J. B \& Sternberg, R. J. (1987). Teaching Thinking Skills : Theory and Practice. New York: W. H. Freeman and Company.

Daniel, Farida (2016). Kemampuan Berfikir Kritis Siswa Pada Implementasi Project Based Learning (PJBL) Berpendekatan Saintifik. Jurnal Pendidikan Matematika Indonesia, volume 1 (1), Halaman 7-13 Tahun 2016.

Depdiknas. 2007. Model-model Pembelajaran Matematika dan Ilmu Pengetahuan

Ennis, R.H. (1991). Critical Thinking: A Streamlined Conception [versi elektronik]. Teaching Philasophy.

Hidayanti, Dwi (2016). Analisis Kemampuan Berfikir Kritis Siswa SMP Kelas IX Pada Materi Kesebngunan. Universitas Negeri Malang, ISSN: 2502-6526.

Istarani. (2015). 50 Tipe, Strategi dan Teknik Pembelajaran Kooperatif. Medan: Media Persada

Keren L, Pepkins. 2004. Creative Problem Solving in Math. Artikel dari www.uh.edu

Mahmuda, R dkk. (2015). Pengaruh Model Pembelajaran Creative Problem Solving Terhadap Kemampuan Berfikir Kritis Matematis Siswa di Madrasah Tsanawiyah. Universitas Pendidikan Indonesia. 
NCTM. (2000). Principles and Standards for School Mathematics. United States of America : The National Council of Teachers of Mathematics, Inc
Permendikbud. 2016. Peraturan Menteri Pendidikan dan Kebudayaan Republik Indonesia. Jakarta:Depdikbud 